\title{
Organizational Support and Managers' Ambidexterity in Social Enterprise: The Mediating Role of Emotional Intelligence
}

\author{
Yujie Feng, Junxing Zhou \\ University of Science and Technology of China, Hefei, China \\ Email: fyj19930@mail.ustc.edu.com
}

How to cite this paper: Feng, Y.J. and Zhou, J.X. (2019) Organizational Support and Managers' Ambidexterity in Social Enterprise: The Mediating Role of Emotional Intelligence. Open Journal of Social Sciences, 7, 259-275.

https://doi.org/10.4236/jss.2019.75023

Received: April 24, 2019

Accepted: May 26, 2019

Published: May 29, 2019

Copyright () 2019 by author(s) and Scientific Research Publishing Inc. This work is licensed under the Creative Commons Attribution International License (CC BY 4.0).

http://creativecommons.org/licenses/by/4.0/

(c) (i) Open Access

\begin{abstract}
The research on organizational innovation has considered structural ambidexterity, context ambidexterity and leadership ambidexterity as important ways to realize organizational ambidexterity. Yet, our understanding about the manager's ambidexterity in social enterprises is still unclear. In order to discover the importance of organizational support, we divided organizational support into instrumental support and emotional support to investigate their impact on manager's ambidexterity. We also argue that emotional intelligence intermediates the relationship between two types of support and manager's ambidexterity in social enterprises; the manager's informal networks and equity sensitivity moderate the impact of the two organizational supports on manager's ambidexterity. In this paper, we propose a research framework that both organizational supports are important determinants of manager's ambidexterity. In addition, emotional intelligence and informal network play a partial mediating role in the two organizational supports and manager's ambidexterity.
\end{abstract}

\section{Keywords}

Social Enterprise, Managers' Ambidexterity, Emotional Intelligence, Informal Network, Equity Sensitivity

\section{Introduction}

Facing the dynamic internal and external environment, exploitation innovation or exploration innovation is difficult to adapt to the needs of organizational development. Enterprises need to focus not only on the development of existing resources, technologies and markets, but also to break the original development 
model and discover new competitive advantages to enhance environmental adaptability and flexibility. The model of pursuing exploitative and exploratory innovation simultaneously is defined as ambidextrous innovation [1] [2]. Organizational ambidexterity has gradually developed into a specific business strategy of various types of firms, as an important factor influencing the success of the organization. At present, most of the ambidextrous research has paid more attention to large enterprises and found that large enterprises can achieve balanced ambidexterity and even combined ambidexterity through spatial separation, time separation and external alliance [3]. The approach of large enterprises to be ambidextrous is not fully applicable to social enterprises due to the significant difference between them in terms of resource endowments and external resource acquisition capacity [4]. Social enterprise exploratory innovation emphasizes social enterprises with innovative thinking and technology, subversive and long-term solution to social problems. Solving such social problems requires social enterprises to conduct in-depth social analysis, have innovative operating models and new products or services. And social enterprise use-type innovation emphasizes that social enterprises use existing scientific and technological means and operational models to solve urgent problems in social development. Considering limited resources and the lack of legal status, social enterprises are often at disadvantaged and passive status in process of ambidextrous innovation. Single exploitative innovation is more conducive to the development of small and medium-sized enterprises [5] [6]. There are relatively scarce studies on the ambidextrous innovation of social enterprises in the existing research, but social enterprise is an important means to solve social problems, increase social welfare, create employment, and promote social innovation. Therefore, tracing how to realize ambidextrous innovation for the survival and development of social enterprises, can carry important benefits for research and practice.

The limitation of resource acquisition and organizational structure in social enterprises makes it difficult to realize the collaborative development of exploitative and exploratory innovation through structural separation. This requires the social enterprises to shift the focus from the organizational dimension to individual dimension, which is an important way to achieve organizational ambidexterity by improving employee's capability. In social enterprises, the choice of organizational strategy mainly depends on the managers' decisions on two innovative activities and managers' ambidexterity is one of the important paths to achieve organizational ambidexterity [7]. Gibson and Birkinshaw initiated individual ambidexterity and emphasized the significance of creating organizational contexts [8]. Managers' ambidexterity, as a special way to achieve both innovations simultaneously, requires managers to deal with contradictory activities, take the responsibility of multitasks, both refine and renew their knowledge, skills and expertise [9]. At the same time, in order to expand the manager's own knowledge and information resources, it is essential to strengthen external learning and share resources within the organization through mastering infor- 
mation from the upper level of senior leaders and subordinate employees [10]. That makes it easy to refresh the existing knowledge and broaden the scope of acquiring knowledge. In order to fill the gaps in the current research, how to realize individual ambidexterity has emerged as an important theme.

Managers' ambidexterity requires the organization to have appropriate internal organizational model and cooperation mechanism, so social enterprises need to create a positive organizational atmosphere and context to improve the manager's personal ambidextrous ability for the pursuit of the balance between exploitative and exploratory innovation within the same organization [11]. Previous research has shown that organizational support as an important means of creating organizational context can influence the manager's personal ability, motivation incentives and opportunities' judgement, which will directly affect the realization of ambidextrous innovation [12] [13] [14]. Little attention has given to the relationship between organizational support and social entrepreneurs' ambidexterity. The limited resources in social enterprises have forced them to adjust strategies that more rely on the manager's personal ability to organize and utilize the internal complementary resources.

Furthermore, organizational support that has an impact on work commitment and work input emphasizes the interaction between organization and employees [15], and provides organizational context for managers to achieve the ambidexterity of individual dimensions. Because the refinement and renewal of knowledge and skills will be helpful to social entrepreneurs' ambidexterity, relying on the interaction of internal information resources. Moreover, interpersonal relationship affects the exchange of resources and the acquisition of information among managers, senior leaders, subordinate employees and the peer manager, while the manager's emotional intelligence is an important factor influencing the team's interpersonal relationship. Previous researchers have observed that organizational support can lead to the development of emotional intelligence [16] [17]. We argue that emotional intelligence plays a mediating role between organizational support and manager ambidexterity. Firstly, emotional intelligence will not only promote the release of manager's own pressure to enhance the enthusiasm of engaging in multi-tasks and extra-role behavior, but also make the manager have a strong sense of organizational identity and keep behaviour consist with the objective of organization. Secondly, it makes managers successfully deal with contradictory innovation activities and ensures that individuals can flexibly shift from one to another between two innovative activities by using the complementary resources within the organization to improve organizational adaptability [18]. In addition, the characteristics of the manager's individual informal network within the organization will influence the manager's ability to participate in cross-sector activities, information acquisition, which regulates manager's expectation of risk, the perception of stress and emotional expression and control [19]. And organizational fairness directly affects the manager's perception of organizational support [20]. In the extant studies, there has not been 
theoretical and empirical research about whether the sensitivity of equity can moderate the relationship between organizational support and emotional intelligence.

This paper will combine organizational support theory and social exchange theory, focusing on the relationship between organizational support (instrumental support and emotional support) and manager ambidexterity to analyze the effect of two different organizational support on manager ambidexterity in social enterprise. Then we pay attention to the mediating role of emotional intelligence on the relationship between organizational support and manager duality. At the same time, we propose the moderate effect of the team diversity and the characteristics of manager's personal informal network on the relationship between organizational support and emotional intelligence to make social enterprises can flexibly choose different organizational support methods of ambidexterity according to their own organisational characteristics.

\section{Organizational Support and Manager Ambidexterity}

The manager's ambiexterity is to examine how firms can achieve duality in individual dimensions and discover the role managers play in ambidextrous innovation through the characteristics of manager's decision-making within the organization [21]. According to the basic features of organizational ambidexterity, it requires the simultaneous development of exploitative innovation and exploratory innovation.

Exploitative innovation implies firm behaviors characterized by refining and improving the existing capacity, technology, knowledge and focuses on the short-term development efficiency of enterprises; while exploratory innovation implies firm behaviors characterized by searching for the new technology, market, business model and focuses on the long-term development and adaptability of enterprises [22]. Managers have to be engaged in routine activities and non-routine activities and focus on the learning about explicit and tacit knowledge. So it is necessary to deepen the understanding of existing knowledge and broaden the scope of knowledge reservation [23]. To sum up, the previous literature has shown the following three basic characteristics of manager's ambidexterity: tolerate and deal with internal contradictory activities, predict changes internal and external environment, discover new market opportunities and enhance the existing capacity, host contradictions to deal with the balance and conflict between short-term efficiency and long-term benefits [7] [24] [25]; fulfill multiple roles and deal with multiple tasks, carry out a variety of innovative activities besides their existing actions at a certain time [26]; ambidextrous managers not only need to improve their existing knowledge and skills, but also need to learn new knowledge and skills to become generalists in all areas, not specialists in a particular field [27] [28].

According to organizational support theory, organizational support mainly refers to all kinds of material and spiritual support that organizations provide 
and their concerns of employees' interest. Organizational support reflects that the organization's commitment and perceived support of individuals about how the organization appraises their contributions and cares for their interests [29]. Based on the principles of social exchange theory, organizational support creates a positive organizational context that increases the efficiency of the organization's teams, influencing individual job satisfaction and creativity [30] [31]. The existing studies have argued that organizational support can be categorized according to different criteria. With the consideration of the content and treatment, organizational support can be divided into fair, autonomy, authority, performance incentives, work environments and so on [32] [33]. Also, in view of the source of support, it can be classified into senior leaders' support, the subordinate's support and the peer managers' support. In this paper, we integrate the classification of organizational support from previous research and differentiate instrumental support from emotional support. Instrumental support consists of resources, training, information and rewarding incentives, while emotional mainly refers to fair treatment, respect, trust, encouragement, concerns about personal development, and decision-making autonomy. Precisely, manager's ambidexterity requires the organization to create a suitable context to encourage managers to flexibly choose the appropriate innovative activities to adapt to changes of environment and arrange his or her own work to satisfy the desire for the pursuit of exploitative innovation and exploratory innovation. Therefore, organisational support is necessary for the realization of manager ambidexterity in social enterprises, which affects the construction of organizational context and the obtainment of the dynamic ability.

Instrumental support mainly refers to the solution of related issues and material resources such as financial resources, information and platforms, which more stimulates extrinsic motivations of managers [34]. External motivation can directly improve the work enthusiasm of the managers so that the formation of a firm psychological contract and exchange commitments between the organization and individuals will make managers endeavor to improve the performance of work and autonomy in order to facilitate the exchange with the organization and obtain more support [35] [36] [37]. Financial and other enterprises performance incentives will guide the managers to contrast their income within the organization. Obviously, they find that high-input and high-risk work will bring them much more return, it may be better for them to make full use of the organization's training platform to improve their abilities and expertise of two innovative activities [38]. And the informational support for conflict tasks provided by the organization can properly adjust and release the pressure of the balance between the two types of innovations, which is conducive to the development of existing work in depth and decrease of distributing attention for adapting to the dynamic changes in the external environment. The sources of information support can be top-down, bottom-up, or managerial counterparts. The existing studies have found that the horizontal and vertical information of the three sources is beneficial to the manager's ambidexterity [39] [40]. In view of social exchange 
theory, higher organizational support that managers acquire from the organization will result in a intensive job commitment, which not only promotes the efficiency of the in-role work but also carries out more extra-role behavior [41] [42]. For example, on one hand, periodical job-rotation activities will not only promote the exchange of information and sharing of emotions among higher level leaders, peer managers at the same level and other subordinates and also enhance the perception of job pressure between the managers; on the other hand the managers can make decisions more flexible and avoid excessive investment in a particular innovation. Under the stimulation of material and information resources, managers will try to do best in order to achieve performance goals, while will actively seek opportunities outside of work to make themselves more willing to accept multi-tasks [43]. In order to achieve a greater return on the instrument, the manager will take the initiative to cooperate with other departments and participate in the activities of other departments, At the same time, they will carry out social learning and promote the flow of knowledge within the organization to make up for their own lack of knowledge through the establishment of internal social network. Thus, instrumental support has a positive effect on the manager's ambidexterity of the organization.

Hypothesis 1: Instrumental support in social enterprise will be positively related to social managers' ambidexterity.

Emotional support is primarily concerned with the care, respect and trust from organisations, which mainly triggers managers' intrinsic motivation. It will increase the manager's engaging and emotional gratitude to the organization [44] and reduce the constraint of formalized mechanisms on managerial behavior [45] [46]. Greater decision-making autonomy stimulates their enthusiastic of work and willingness to undertake multi-tasks. Emotional support also includes trust and decentralization of the senior management team, the support and cooperation of the subordinates and the care and interaction between the manager peers [47]. Firstly, emotional support will have a lasting impact on managers' personal development and will make them have a strong sense of belonging and organizational identity so that their personal goals and decision-making can maintain consistency with organizational goals by exploiting the original work advantage to improve work efficiency [48]. Secondly, emotional communication within the organization encourages managers to engage in extra-role behaviors, which promotes information exchange between departments, enhances confidence in dealing with risks, and mitigates psychological stress from conflict tasks [49]. Thirdly, the emotional support from peer managers of other departments will break the boundaries of the department and initiate more organizational citizenship behaviors that show more help behavior and promote the organization's knowledge sharing to realize the complement of managers' resources and ability [50]. This will facilitate managers' external learning of the manager in order to promote learning of knowledge and skills in the existing department and the capability of dealing with contradictory activities force themselves into new areas to participate in innovative activities in oth- 
er sectors. Social enterprise's internal management is more dispersed. Therefore, in the face of emotional support provided by the organization, managers' initiative sharing behavior and the formation of multi-directional multi-dimensional harmonious organization atmosphere will enable the limited resources integrated within the social enterprises to improve their ability of reconfiguring the organizational resources quickly according to the environment changes. It can be seen that emotional support enables managers to generate strong organizational commitment and organizational loyalty. They will both focus on exploitative innovation to enhance the efficiency of the sector and strengthen cooperation with other departments to promote cross-sector exploratory innovation.

Hypothesis 2: Emotional support in social enterprise will be positively related to managers' ambidexterity.

\section{Mediating Role of Emotional Intelligence}

Managers' ambidexterity requires the existence of knowledge sharing and cross-sector cooperation within the organization. Poor coordination among departments, the phenomenon of low efficiency and the lack of communication between departments often exist in social enterprises [51]. In addition, the lack of reasonable organizational structure in social enterprises leads to the emergence of organizational overlap or gaps, limited departmental functions and the protectionism of their own sector's interest, which will narrow the scope of the use of knowledge within the organization and have a negative effect on the formation of duality ambidexterity [52]. The elimination of the emotional bias in the manager is an important prerequisite to achieve manager ambidexterity for social enterprises.

Emotion is an important concept of cognitive psychology, which refers to the human subjective experience of objective things. Emotion is not only affected by the external environment, but also by the individual's behavioral tendencies. Emotional intelligence, as an ability to identify and understand the emotional state of yourself and others, can be used to solve problems and regulate behavior [16]. Emotional perception, emotional use, emotional understanding and emotional management are emotional intelligence. In other words, whether we can understand the emotions of ourselves and others well, whether we can control our emotions, etc. are all manifestations of emotional intelligence. It can be seen as the individual's comprehensive ability to deal with emotional processing, which mainly includes emotional perception, emotional understanding, emotional use and emotional management [53]. In the studies of organizational emotion, it is found that the organizational characteristics are the antecedent variables that affect the individual moods. The diversity and complexity of organizational tasks will affect the expression of personal emotion. In social enterprise, managerial ambidexterity is an important approach for achieving organizational ambidexterity. Managers' emotions directly influence their decision-making and contextual support with the organization shapes manager's emotional intelli- 
gence.

Instrumental support provided by the organization, especially information and resources, allows managers to make positive predictions by increasing flexibility of decision-making and creative thinking. Besides, it enhances the managers' confidence to accomplish multiple tasks and make them proactively regulate personal emotions to adapt to ambidextrous activities. What's more, instrumental support will make it convenient for managers to forecast and perceive others' emotions. Emotional support provided by the organization, including respect, trust and concern from the superior, subordinate and other managers will inspire managers' emotional intelligence. Firstly, emotional support will promote interpersonal communication to create a harmonious organizational atmosphere. It's beneficial to enhance the cohesion by facilitating information sharing and emotional interaction which makes them more expert in identify emotions of themselves and others. This will help managers to identify themselves and others "emotions, understand conflicting emotions, and better predict their own and others" emotions. Secondly, emotional support will endow managers with greater decision-making power and tolerance of errors so that they can improve their own ability to withstand pressure and cope with risk, which helps managers regulate emotions to hold positive and optimistic attitude towards failure and contradictory innovation activities. In terms of emotional regulation, organizational supports will enable managers to self-discipline and self-motivate based on the principles of social exchange [54]. Managers will generate a positive and optimistic emotional state of the work environment and tasks and become more confident in dealing with complex and conflicting tasks with the support of the organization [55]. In terms of emotional management, organizational support will help managers to regulate negative emotions rapidly and relieve emotional stress to respond positively to conflict activities [56].

Hypothesis 3a: Organizational instrumental support is positively related to managers' emotional intelligence.

Hypothesis 3b: Organizational Emotional Support is positively related to managers' emotional intelligence.

Organizational characteristics affect the development of emotional intelligence, while emotional intelligence will also have a positive impact on the manager's ambidexterity. For many social enterprises, the limitations of resources make it take up greater internal pressure and external risk, so emotional intelligence is a basic capability that managers must have in social enterprise. In contrast with low emotional intelligence, higher emotional intelligence will make managers more likely to adapt to organizational and environmental changes. Managers with higher emotional intelligence are skilled in using their own emotional incentives and emotional management to cooperate with other members and making full use of internal and external resources to play different roles in different circumstances. Besides, Existing studies have found the mediating role of emotional intelligence in many fields. For example, psychological scholars find the mediating role of emotional intelligence in the relationship between so- 
cial support and individual adaptability. And emotions are mediators of external factors and individual creativity [57] [58]. Managerial scholars found that social support will affect individual emotions, and then affect organizational innovation [59].

Following the above assumptions, emotional intelligence not only affects the expression and identification of emotions. More importantly, it has the function of emotional regulation and management, which has a very important impact on social entrepreneurs' ambidexterity. Firstly, emotional regulation can make managers express appropriate emotion according to the characteristics of the work and changes in the environment.

In the face of complex and conflict work, managers can regulate emotions timely to moderate stress and discomfort. So they will have the motivation and confidence to pursue a range of conflicting opportunities and goals and deal with contradictory activities to meet the requirements of manager's ambidexterity [60]. Secondly, emotional management can promote self-motivation of managers and make them always maintain an optimistic state of mind. They are willing to host contradiction and take up multi-tasks. Prior research has indicated the importance of different kinds of knowledge and information for managers to realize ambidexterity. Related to this, self-motivation triggered by emotional intelligence will encourage managers to refine and renew the knowledge skills and expertise through learning imitatively. This will reinforce the efficiency of existing work and elaborate the adaptability to new needs and opportunities. Thirdly, emotional perception will enhance the manager's interpersonal communication skills with superior, subordinates and colleagues. Managers can better understand the emotional changes of others to facilitate mutual interaction and knowledge sharing within the organization [61] [62]. Frequent interpersonal communication will increase the trust between managers and promote cross-sector cooperation to pursue common organizational goals [63] [64]. In the process of coordination, managers with higher emotional intelligence will not only consider their own competencies, but also to consider the benefits, goals and values of others. Furthermore, cross-sector cooperation and participation strive managers to carry more extra-role behaviors and external learning to obtain different information and update their own knowledge and skills.

Hypothesis 4a: Emotional intelligence plays a mediating role between instrumental support and managers' ambidexterity. Emotional intelligence is positively related to managers' ambidexterity.

Hypothesis 4b: Emotional intelligence plays a mediating role between emotional support and social entrepreneurs' ambidexterity. Emotional intelligence is positively related to managers' ambidexterity.

\section{The Moderate Effect of Manager's Informal Network}

The formal network refers to the organization's basic "bones" to ensure the normal organizational functions while informal network can breakthrough or- 
ganizational boundaries to promote free communication and connection. The informal network consists of the individual social or interpersonal relationships and develops by trust and moral constraints [65]. The manager is an important node of the internal social network and the construction of the informal network has an important influence on the information exchange within the organization. The existing studies have found that the individual informal network affects knowledge sharing especially invisible knowledge and plays an active role in the organization's exploratory innovation [66]. In addition, the information, knowledge and resources flow faster in the informal network than formal network.

And previous literature has argued that higher happiness directly affects the improvement and development of emotional intelligence. Informal network will enhance their well-being and enthusiasm of taking up multiple tasks because it often make managers acquire more information and resources and integrate different organizational support effectively to generate more heterogeneous resources [67]. Moreover, informal network based on trust and moral can place greater dependency among managers, superiors and subordinates. Members in the network can better predict emotions and behaviors of themselves and others by communication and interaction (Krackhardt \& Hanson, 1993; Kluemper et al., 2009). It will make managers gain more confidence of the manager when they obtain organizational support and regulate emotions swiftly to decrease the sense of pressure on conflicting work because informal network make it easier to participate in cross-sector cooperation. Furthermore, the informal network as a supplement of emotional support will show more opportunities for managers to communicate with other individuals and greater frequency of communication. In this process, it will not only focus on changes of their own emotions, but also pay attention to the emotional changes of other members in the network, which is conducive to promote manager's abilities of emotional recognition and emotional understanding. Thus, the manager's informal network has a significant moderate impact on the relationship between organizational support and emotional intelligence.

Hypothesis 5a: The manager's personal informal network moderates the relationship between instrumental support and emotional intelligence, such that instrumental support is more positively associated with emotional intelligence as the density of informal network increases.

Hypothesis 5b: The manager's personal informal network moderates the relationship between emotional support and emotional intelligence, such that emotional support is more positively associated with emotional intelligence as the density of informal network increases.

\section{The Moderate Effect of Manager's Equity Sensitivity}

Equity sensitivity is a more independent and stable personality characteristic which refers to the individual differences of perception about the equity and jus- 
tice [68]. Different individuals have different perceptions and sensitivity of equity. Managers who are highly sensitive to equity will feel more unfair in the event than selfless ones and become more selfish. It will make managers generate a series of negative emotional reactions and affect the individual subsequent decision making and behaviors [69].

Organizational support will have a positive effect on the individual's work engagement and enthusiasm only when they are perceived timely and accurately. In the process of perception, managers will conduct social comparisons of organizational support with others. Organizational justice has an impact on manager's commitment to work and organizational citizenship behavior [70] [71]. Firstly, equity sensitivity regulates managers' perception of organizational support, such that managers with higher equity sensitivity have more unfair perception of organizational support, which creates negative emotions and the confidence acquired from organizational support will be weakened. The negative emotions will reduce manager's self-motivation and initiative to multiple tasks, resulting in more job burnout behavior. Secondly, the unfair perception of organizational support will increase the manager's perception of pressure about conflicting work, which directly affects his emotional regulation and control. It's difficult for managers to remain active and optimistic in the state of mind. They may make wrong understanding on the emotions of themselves and others because of emotional fluctuations. Thirdly, managers with high equity sensitivity will take some measures to compensate for this imbalance after gaining unfair perception, which can result in the closure of information and hostility between departments as a result of competition for limited resources. The organizational atmosphere remains highly tense, which will further weaken the positive impact of organizational support on emotional intelligence.

Hypothesis 6a: The manager's equity sensitivity moderates the relationship between instrumental support and emotional intelligence, such that instrumental support is less positively associated with emotional intelligence as equity sensitivity increases.

Hypothesis 6b: The manager's equity sensitivity moderates the relationship between emotional support and emotional intelligence, such that emotional support is less positively associated with emotional intelligence as equity sensitivity increases.

Based on the above six hypothesis, we construct a moderated mediator model as shown in the following Figure 1.

\section{Conclusions}

The social exchange theory argues that organizational support will enable individuals to generate stronger organizational commitment and then influence the complexity and diversity of individual organizational behavior. Previous studies have identified important factors that influence managerial ambidexterity, such as managerial decision-making authority, access to internal information and 


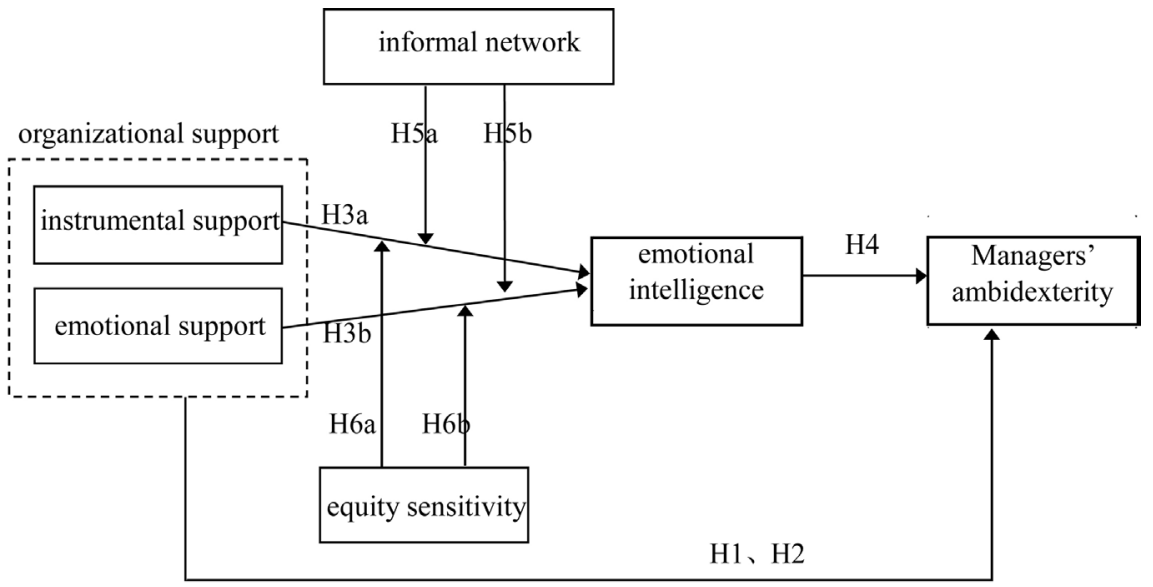

Figure 1. Theoretical hypothesis model.

cross-sector cooperation, which are important components of organizational support. Combined two different perspectives (social exchange \& organizational identification) to analyze the effectiveness of organizational support, our research provides evidence that instrumental support and emotional support are the determinant factors for manager's ambidexterity. Under the support of organizations, managers can not only successfully undertake multiple tasks and deal with contradictory innovation activities, but also carry out cross-sector cooperation, organizational learning and information exchange to achieve ambidexterity.

Our study also found the mediating role of emotional intelligence between the two organizational supports and manager's ambidexterity. Many psychological scholars have studied the influence of social support on emotional intelligence and found that perceived social support was positively related to emotional intelligence. This study introduces the influence of social support on emotional intelligence into the field of management. Managers with high emotional intelligence can perceive organization support much better. The effect of organizational support will be amplified. In this paper, the psychological mechanism of stimulus-emotion-behavior is applied to the relationship between organizational support and manager's ambidexterity. Our hypothesis supports the conceptual model of social support and individual adaptability proposed by Wills \& Cleary, which emphasizes the individual's psychological processes, especially the importance of individual emotional management.

In addition, we also argue that informal networks increase the effectiveness of the two organizational supports on emotional intelligence. The informal network will further promote the diffusion of invisible knowledge and improve the speed of knowledge and information flow, which gives managers more confidence to complete multiple tasks.

However, this study only provides a research framework and does not conduct empirical tests. The reason is that the relevant development of domestic social enterprises is still immature, relevant disclosure is imperfect, data collection is difficult, and the measurement tools of social enterprises are immature. Future 
research can test the framework in an empirical way to support the mechanism of "organizational support-emotional intelligence-innovative behavior".

\section{Conflicts of Interest}

The authors declare no conflicts of interest regarding the publication of this paper.

\section{References}

[1] Tushman, O. (1996) The Ambidextrous Organizations: Managing Evolutionary and Revolutionary Change. California Management Review, 38, 8-30. https://doi.org/10.2307/41165852

[2] He, Z.L. and Wong, P.K. (2004) Exploration vs. Exploitation: An Empirical Test of the Ambidexterity Hypothesis. Organisation Science, 15, 481-494. https://doi.org/10.1287/orsc.1040.0078

[3] Siggelkow, N. and Levinthal, D.A. (2003) Temporarily Divide to Conquer: Centralized, Decentralized, and Reintegrated Organizational Approaches to Exploration and Adaptation. Organisation Science, 14, 650-669. https://doi.org/10.1287/orsc.14.6.650.24840

[4] Lubatkin, M.H., Simsek, Z., Ling, Y. and Veiga, J.F. (2006) Ambidexterity and Performance in Small- to Medium-Sized Firms: The Pivotal Role of Tom Management Team Behavioral Integration. Journal of Management, 32, 646-672. https://doi.org/10.1177/0149206306290712

[5] Lee, S., Park, G., Yoon, B. and Park, J. (2010) Open Innovation in SMEs-An Intermediated Network Model. Research Policy, 39, 290-300. https://doi.org/10.1016/j.respol.2009.12.009

[6] Yang, H., Zheng, Y. and Zhao, X. (2014) Exploration or Exploitation? Small Firms' Alliance Strategies with Large Firms. Strategic Management Journal, 35, 146-157. https://doi.org/10.1002/smj.2082

[7] Smith, W.K. and Tushman, M.L. (2005) Managing Strategic Contradictions: A Top Management Model for Managing Innovation Streams. Organization Science, 16, 522-536. https://doi.org/10.1287/orsc.1050.0134

[8] Gibson, J.B. (2004) The Antecedents, Consequences, and Mediating Role of Organizational Ambidexterity. Academy of Management Journal, 47, 209-226. https://doi.org/10.2307/20159573

[9] Mom, T.J.M., et al. (2009) Understanding Variation in Managers' Ambidexterity: Investigating Direct and Interaction Effects of Formal. Organization Science, 20, 812-828. https://doi.org/10.1287/orsc.1090.0427

[10] Mom, T.J.M., et al. (2007) Investigating Managers' Exploration and Exploitation Activities: The Influence of Top-Down, Bottom-Up, and Horizontal Knowledge Inflows. Journal of Management Studies, 44, 910-931. https://doi.org/10.1111/j.1467-6486.2007.00697.x

[11] Chang, Y.Y. and Hughes, M. (2012) Drivers of Innovation Ambidexterity in Smallto Medium-Sized Firms. European Management Journal, 30, 1-17. https://doi.org/10.1016/j.emj.2011.08.003

[12] Witt, L.A. (1991) Exchange Ideology as a Moderator of Job-Attitudes Organizational Citizenship Behaviors Relationships. Journal of Applied Social Psychology, 21, 1490-1501. https://doi.org/10.1111/j.1559-1816.1991.tb00483.x 
[13] George, J.M. and Brief, A.P. (1992) Feeling Good-Doing Good: A Conceptual Analysis of the Mood at Work-Organizational Spontaneity Relationship. Psychological Bulletin, 112, 310-329. https://doi.org/10.1037/0033-2909.112.2.310

[14] Rhoades, L. and Eisenberger, R. (2002) Perceived Organizational Support: A Review of the Literature. Journal of Applied Psychology, 87, 698-714. https://doi.org/10.1037/0021-9010.87.4.698

[15] Eisenberger, R., Armeli, S., Rexwinkel, B., Lynch, P.D. and Rhoades, L. (2001) Reciprocation of Perceived Organizational Support. Journal of Applied Psychology, 86, 42-51. https://doi.org/10.1037//0021-9010.86.1.42

[16] Mayer, J.D. and Salovey, P. (1997) What Is Emotional Intelligence? In: Salovey, P. and Sluyter, D., Eds., Emotional Development and Emotional Intelligence: Educational Implications, Basic Books, New York, 3-31.

[17] Tu, Y. and Lu, X. (2013) How Ethical Leadership Influence Employees' Innovative Work Behavior: A Perspective of Intrinsic Motivation. Journal of Business Ethics, 116, 441-455. https://doi.org/10.1007/s10551-012-1455-7

[18] Rode, J.C., et al. (2007) Emotional Intelligence and Individual Performance: Evidence of Direct and Moderated Effects. Journal of Organizational Behavior, 28, 399-421. https://doi.org/10.1002/job.429

[19] Heavey, C., Simsek, Z. and Fox, B.C. (2015) Managerial Social Networks and Ambidexterity of SMEs: The Moderating Role of a Proactive Commitment to Innovation. Human Resource Management, 54, s201-s221.

https://doi.org/10.1002/hrm.21703

[20] Eisenberger, R., Huntington, R., Hutchison, S. and Sowa, D. (1986) Perceived Organizational Support. Journal of Applied Psychology, 71, 500-507. https://doi.org/10.1037//0021-9010.71.3.500

[21] Rivkin, J.W. and Siggelkow, N. (2003) Balancing Search and Stability: Interdependencies among Elements of Organizational Design. Management Science, 49, 290-311. https://doi.org/10.1287/mnsc.49.3.290.12740

[22] Adler, P.S., Goldoftas, B. and Levine, D. (1999) Flexibility versus Efficiency? A Case Study of Model Changeovers in the Toyota Production System. Organistion Science, 10, 43-68. https://doi.org/10.1287/orsc.10.1.43

[23] Gupta, A.K., Smith, K.G. and Shalley, C.E. (2006) The Interplay between Exploration and Exploitation. Academy of Management Journal, 49, 693-706. https://doi.org/10.5465/amj.2006.22083026

[24] Duncan, R.B. (1976) The Ambidextrous Organization: Designing Dual Structures for Innovation. The Management of Organization, 1, 167-188.

[25] Floyd, S.W. and Lane, P.J. (2000) Strategizing throughout the Organization: Managing Role Conflict in Strategic Renewal. Academy of Management Review, 25, 154-177. https://doi.org/10.2307/259268

[26] Leana, C.R. and Barry, B. (2000) Stability and Change as Simultaneous Experiences in Organizational Life. Academy of Management Review, 25, 753-759. https://doi.org/10.5465/amr.2000.3707707

[27] Subramaniam, M. and Youndt, M.A. (2005) The Influence of Intellectual Capital on the Types of Innovative Capabilities. Academy of Management Review, 48, 450-463.

[28] Lubatkin, M.H., Simsek, Z., Yan, L. and Veiga, J.F. (2006) Ambidexterity and Performance in Small- to Medium-Sized Firms: The Pivotal Role of Top Management Team Behavioral Integration. Journal of Management, 32, 646-672. https://doi.org/10.1177/0149206306290712 
[29] Abou-Moghli, A. (2015) The Role of Organizational Support in Improving Employees Performance. International Business Research, 8, 198-203. https://doi.org/10.5539/ibr.v8n2p198

[30] Festinger, L. (1954) A Theory of Social Comparison Process. Human Relations, 7, 117-140. https://doi.org/10.1177/001872675400700202

[31] Amabile, T.M., Conti, R., Coon, H., et al. (1996) Assessing the Work Environment for Creativity. Academy of Management Journal, 39, 1154-1184. https://doi.org/10.2307/256995

[32] Rousseau, D.M. and Tijoriwala, S.A. (1998) Assessing Psychological Contracts: Issues, Alternatives and Measures. Journal of Organizational Behavior, 19, 679-695. https://doi.org/10.1002/(SICI)1099-1379(1998)19:1+<679::AID-JOB971>3.0.CO;2$\underline{\mathrm{N}}$

[33] Aryee, S. and Chay, Y.W. (2001) Workplace Justice, Citizenship Behavior, and Turnover Intentions in a Union Context: Examining the Mediating Role of Perceived Union Support and Union Instrumentality. Journal of Applied Psychology, 86, 154-160. https://doi.org/10.1037/0021-9010.86.1.154

[34] Kraimer, M.L. and Wayne, S.J. (2004) An Examination of Perceived Organizational Support as a Multidimensional Construct in the Context of an Expatriate Assignment. Journal of Management, 30, 209-237.

https://doi.org/10.1016/j.jm.2003.01.001

[35] Cohen, A. (1993) Organizational Commitment and Turnover: A Meta-Analysis. Academy of Management Journal, 36, 1140-1157. https://doi.org/10.5465/256650

[36] Allen, D.G., Shore, L.M. and Griffeth, R.W. (2003) The Role of Perceived Organizational Support and Supportive Human Resource Practices in the Turnover. Journal of Management, 29, 99-118. https://doi.org/10.1177/014920630302900107

[37] Wilmar, B., Schaufeli, A. and Bakker, B. (2004) Job Demands, Job Resources and Their Relationship with Burnout and Engagement. Journal of Organizational Behavior, 25, 246-248. https://doi.org/10.1002/job.248

[38] Schaufeli, W.B. and Bakker, A.B. (2004) Job Demands, Job Resources, and Their Relationship with Burnout and Engagement: A Multi-Sample Study. Journal of Organizational Bahavior, 25, 293-315. https://doi.org/10.1002/job.248

[39] Brady, T. and Davies, A. (2004) Building Project Capabilities: From Exploratory to Exploitative Learning. Organization Studies, 25, 1601-1621.

https://doi.org/10.1177/0170840604048002

[40] Branzei, O., Ursacki-Bryant, T.J., Vertinsky, I. and Zhang, W. (2004) The Transformation of Green Strategies in Chinese Firms: Matching Corporate Environmental Responses and Individual Principles. Strategic Management Journal, 25, 1075-1095. https://doi.org/10.1002/smj.409

[41] Organ, D.W. (1998) Organizational Citizenship Behavior: The Good Soldier Syndrome. Lexington Books, Lexington.

[42] Tepper, B.J. and Taylor, E.C. (2003) Relationships among Supervisors' and Subordinates' Procedural Justice Perceptions and Organizational Citizenship Behaviors. Academy of Management Journal, 46, 97-105. https://doi.org/10.2307/30040679

[43] Prieto, I.M. and Santana, M.P.P. (2012) Building Ambidexterity: The Role of Human Resource Practices in the Performance of Firms from Spain. Human Resource Management, 51, 189-211. https://doi.org/10.1002/hrm.21463

[44] Mccullough, M.E., Emmons, R.A. and Tsang, J.A. (2002) The Grateful Disposition: A Conceptual and Empirical Topography. Journal of Personality and Social Psy- 
chology, 82, 112-127. https://doi.org/10.1037/0022-3514.82.1.112

[45] Eisenberger, R., Rhoades, L. and Cameron, J. (1999) Does Pay for Performance Increase or Decrease Perceived Self-Determination and Intrinsic Motivation? Journal of Personality and Social Psychology, 77, 1026-1040. https://doi.org/10.1037//0022-3514.77.5.1026

[46] Crossan, M.M. and Berdrow, I. (2003) Organizational Learning and Strategic Renewal. Strategic Management Journal, 24, 1087-1105.

[47] Settoon, R.P., Bennett, N. and Liden, R.C. (1996) Social Exchange in Organizations: Perceived Organizational Support, Leader-Member Exchange, and Employee Reciprocity. Journal of Applied Psychology, 81, 219-227. https://doi.org/10.1037/0021-9010.81.3.219

[48] Simosi, M. (2010) The Role of Social Socialization Tactics in the Relationship between Socialization Content and Newcomers' Affective Commitment. Journal of Managerial Psychology, 25, 301-327. https://doi.org/10.1108/02683941011023758

[49] Jansen, J.J.P., van den Bosch, F.A.J. and Volberda, H.W. (2005) Managing Potential and Realized Absorptive Capacity: How Do Organizational Antecedents Matter? Academy of Management Review, 48, 999-1015.

https://doi.org/10.5465/amj.2005.19573106

[50] Gupta, A.K. and Govindarajan, V. (2000) Knowledge Flows within Multinational Corporations. Strategic Management Journal, 21, 473-496.

[51] Burcharth, A.L.D.A., Knudsen, M.P. and Søndergaard, H.A. (2014) Neither Invented Nor Shared Here: The Impact and Management of Attitudes for the Adoption of Open Innovation Practices. Technovation, 34, 149-161. https://doi.org/10.1016/j.technovation.2013.11.007

[52] Lichtenthaler, U. (2010) Technology Exploitation in the Context of Open Innovation: Finding the Right “Job” for Your Technology. Technovation, 30, 429-435. https://doi.org/10.1016/j.technovation.2010.04.001

[53] Mayer, C. (1999) Emotional Intelligence Meets Traditional Standards for an Intelligence. Intelligence, 27, 267-298. https://doi.org/10.1016/S0160-2896(99)00016-1

[54] Ciarrochi, C. (2000) A Critical Evaluation of the Emotional Intelligence Concept. Personal Individual Difference, 28, 539-561. https://doi.org/10.1016/S0191-8869(99)00119-1

[55] Kluemper, D.H., Little, L.M. and De Groot, T. (2009) State or Trait: Effects of State Optimism on Job-Related Outcomes. Journal of Organizational Behavior, 30, 209-231. https://doi.org/10.1002/job.591

[56] Lopes, P.N., Salovey, P. and Straus, R. (2003) Emotional Intelligence, Personality, and the Perceived Quality of Social Relationships. Personal and Individual Difference, 35, 641-658. https://doi.org/10.1016/S0191-8869(02)00242-8

[57] Wills, T.A. and Cleary, S.D. (1996) How Are Social Support Effects Mediated? A Test with Parental Support and Adolescent Substance Use. Journal of Personality and Social Psychology, 71, 937-952. https://doi.org/10.1037/0022-3514.71.5.937

[58] Shalley, C.E., et al. (2004) The Effects of Personal and Contextual Characteristics on Creativity: Where Should We Go from Here? Journal of Management, 30, 933-958. https://doi.org/10.1016/j.jm.2004.06.007

[59] Majar, N., et al. (2002) There's No Place like Home? The Contributions of Work and Non-Work Creativity Support to Employees' Creative Performance. Academy of Management Journal, 45, 757-767. https://doi.org/10.5465/3069309

[60] Zhou, J. and George, J.M. (2001) When Job Dissatisfaction Leads to Creativity: En- 
couraging the Expression of Voice. Academy of Management Journal, 44, 682-696. https://doi.org/10.2307/3069410

[61] Mc Allister, D.J. (1995) Affect- and Cognition-Based Trust as Foundations for Interpersonal Cooperation in Organizations. Academy of Management Journal, 38, 24-59. https://doi.org/10.2307/256727

[62] Barczak, G., Lassk, F. and Mulki, J. (2010) Antecedents of Team Creativity: An Examination of Team Emotional Intelligence, Team Trust and Collaborative Culture. Creativity and Innovation Management, 19, 332-345. https://doi.org/10.1111/j.1467-8691.2010.00574.x

[63] Reagans, R. and Zuckerman, E.W. (2001) Networks, Diversity, and Productivity: The Social Capital of Corporate R and D Teams. Organisation Science, 12, 502-517. https://doi.org/10.1287/orsc.12.4.502.10637

[64] Rodan, S. and Galunic, C. (2004) More than Network Structure: How Knowledge Heterogeneity Influences Managerial Performance and Innovativeness. Strategic Management Journal, 25, 541-562. https://doi.org/10.1002/smj.398

[65] Krackhardt, D. and Hanson, J.R. (1993) Informal Networks: The Company behind the Chart. Harvard Business Review, 71, 104-111.

[66] Wenger, E., et al. (2002) Cultivating Communities of Practice: A Guide to Managing Knowledge. Harvard Business School Press, Boston, 4-5.

[67] Cross, R. and Prusakl, L. (2002) The People Who Make Organizations Go-Or Stop. Harvard Business Review, 6, 5-12.

[68] Morrison, E.W. and Robinson, S.L. (1997) When Employees Feel Betrayed: A Model of How Psychological Contract Violation Develops. Academy of Management Review, 22, 226-256. https://doi.org/10.5465/amr.1997.9707180265

[69] Schmitt, M., Baymert, A., Gollwitzer, M. and Maes, J. (2010) The Justice Sensitivity Inventory: Factorial Validity, Location in the Personality Facet Space, Demographic Pattern and Normative Data. Social Justice Research, 23, 211-238. https://doi.org/10.1007/s11211-010-0115-2

[70] Andrews, M.C. and Kacmar, K.M. (2001) Discriminating among Organizational Politics, Justice, and Support. Journal of Organizational Behavior, 22, 347-366. https://doi.org/10.1002/job.92

[71] Kacmar, K.M. and Carlson, D.S. (1997) Further Validation of the Perceptions of Politics Scale: POPS, a Multiple Sample Investigation. Journal of Management, 23, 627-658. https://doi.org/10.1177/014920639702300502 